\begin{tabular}{|c|l|}
\hline Title & Changes in terrestrial organic matter input to the Mendeleev Ridge, western A rctic Ocean, during the Late Quaternary \\
\hline Author(s) & Y amamoto, Masanobu; Polyak, Leonid \\
\hline Citation & $\begin{array}{l}\text { Global and Planetary Change, 68(1-2), 30-37 } \\
\text { https://doi.org/10.1016j.gloplacha.2009.03.012 }\end{array}$ \\
\hline Issue Date & 2009-07 \\
\hline Doc URL & http://hdl.handle.net/2115/39290 \\
\hline Type & article (author version) \\
\hline File Information & GPC68-1-2_p30-37.pdf \\
\hline
\end{tabular}

Instructions for use 


\title{
Changes in terrestrial organic matter input to the Mendeleev Ridge, western Arctic Ocean, during the Late Quaternary
}

\author{
Masanobu Yamamoto ${ }^{\text {a*, Leonid Polyak }}{ }^{\mathrm{b} \text {, }}$ \\ ${ }^{a}$ Faculty of Environmental Earth Science, Hokkaido University, Kita-10, Nishi-5, \\ Kita-ku, Sapporo 060-0810, Japan \\ b Byrd Polar Research Center, Ohio State University, 1090 Carmack Road, \\ Columbus, OH 43210, USA \\ * Corresponding author. E-mail address: myama@ees.hokudai.ac.jp (M. \\ Yamamoto).
}

\begin{abstract}
Hydrocarbons and glycerol dialkyl glycerol tetraethers (GDGTs) were analyzed in Late Pleistocene sediments of Core HLY0503-08JPC collected at the Mendeleev Ridge during the Healy-Oden Trans Arctic Expedition 2005 (HOTRAX'05) to investigate environmental changes in the western Arctic Ocean during the last full glacial cycle, ca. $130 \mathrm{kyr}$. Variations in long-chain n-alkane and GDGT concentrations correspond to alternated color banding, brown (interglacial/interstadial) and grayish (glacial/stadial) layers. Grayish layers are characterized by abundant higher plant n-alkanes and branched GDGTs, implying larger contribution of terrestrial plant and soil organic matter $(\mathrm{OM})$ in glacial environments, possibly due to the deposition of fine-grained products of glacial erosion in the Amerasian basin. Lithic n-alkanes derived from mature OM show pronounced peaks, which can be classified into six types presumably indicative of various sediment sources. Some peaks are correlated to events of iceberg discharge and freshwater outbursts from proglacial lakes of the Eurasian and, possibly, Laurentide ice sheets, suggesting that other peaks may correspond to similar events.
\end{abstract}

Keywords; Arctic, biomarker, tetraethers, glacial, HOTRAX'05, ice rafted debris, paleoenvironment.

\section{Introduction}

The Arctic Ocean plays a major role in global climate changes by changing global energy balance through ice-albedo feedback and by affecting the oceanic thermohaline circulation through the water exchange with the Atlantic and Pacific oceans (Aagaard and Carmack, 1989; Delworth et al., 1997; Smith et al., 2002). A complete understanding of the role of the Arctic Ocean in global climate changes requires records of the formation and coverage of iceberg and sea ice during past periods.

Icebergs and sea ice deliver ice-rafted debris (IRD), which has been used to reconstruct the Arctic's iceberg and sea ice formation history (e.g., Bischof et al., 1996; Polyak et al., 2004; Spielhagen et al., 2004). IRD source areas have been determined using mineral and chemical compositions (e.g., Stein et al., 1994; 
Bischof and Darby, 1997; Darby et al., 2002). Organic geochemistry has also been applied in such studies; the amount and quality of bulk OM have been reported for sediment cores from the Amundsen Basin (Schubert and Stein, 1996) and the Siberian continental margins (Stein et al., 2001, 2004; Bouscein et al., 2002). Biomarkers are also used as source-specific tracers in oceanographic studies in the central Arctic Ocean (Schubert and Stein, 1997; Belicka et al., 2002; Yunker et al., 2005), the northern Eurasian margin (Peulvé et al., 1996; Fahl and Stein, 1997; Zegouagh et al., 1996) and North American margins (Yunker et al., 1995; Belicka et al., 2004), and in paleoceanographic studies in Holocene and late Pleistocene sequences of the Laptev and Kara Seas (Fahl and Stein, 1999; Stein et al., 2001), and the Lomonosov Ridge in the central Arctic (Yamamoto et al., 2008).

Detrital matter is mostly transported to the central Arctic Ocean by ice rafts; fine sediment can be also carried by intermediate-depth currents. Under present conditions the Transpolar Drift transports sediment-laden "dirty" sea ice from the Laptev Sea; eastward boundary currents along the northwestern Siberian margin and clockwise water circulation in the Beaufort gyre join with the Transpolar Drift (Gordienko and Laktionov, 1969; see Fig. 1) to contribute to mass transportation by ice-drift streams (Nürnberg et al., 1994).

We examined late Pleistocene biomarker records collected from the 2005 Healy-Oden Trans Arctic Expedition (HOTRAX'05) at the Mendeleev Ridge in the western Arctic Ocean, with the goal of understanding glacial-interglacial variation in biomarker composition in the Arctic Ocean and their relationship to late Pleistocene climate change. The results indicate drastic changes in biomarker composition with glacial-interglacial variation, which is discussed in relation to changes in sediment delivery mechanisms and source areas, and the expansion and disintegration of the Eurasian and North American ice sheets.

\section{Materials and methods}

\subsection{Samples}

The Mendeleev Ridge is an elevated portion of the Arctic Ocean floor extending northwards from the East Siberian shelf. Core HLY0503-08JPC, ca. $12 \mathrm{~m}$ long, was collected on the Mendeleev Ridge (79³5.6' $\left.\mathrm{N}, 172^{\circ} 30.1^{\prime} \mathrm{W}\right)$ at a water depth of $2792 \mathrm{~m}$ in the western Arctic Ocean on the 2005 Healy-Oden Trans Arctic Expedition (HOTRAX'05) (Darby et al., 2005; Fig. 1).

The core site is located close to the area of interaction of the two major Arctic Ocean circulation systems, the Beaufort Gyre and the Transpolar Drift (Fig. 1), and is thus affected by deposition of both North American and Eurasian sediment rafted by sea ice and/or icebergs (Adler et al., this volume). In addition, fine-grained material may be transported by water current that flows at intermediate water depths along the Eurasian slope. Comparison with other cores from the Mendeleev Ridge collected during HOTRAX'05 and earlier expeditions (Clark et al., 1980; Darby et al., 1997; Poore et al., 1999; Polyak et al., 2004) indicates that Core HLY0503-08JPC has relatively elevated sedimentation rates resulting probably from its location at a local depocenter at the bottom of the eastern flank of the ridge (Adler et al., this volume). Enhanced sedimentation rates combined with a strategic location at a junction of two 
major circulation and sedimentation pathways makes Core HLY0503-08JPC well suited for a detailed investigation of sedimentary environments in the Amerasian Basin of the Arctic Ocean.

Sediments comprise mud and sandy mud with strong color banding mainly "grayish" layers (yellowish brown to olive brown) and "brown" layers (brown to dark brown) (Adler et al., this volume). Color bands range in thickness from 2 to $35 \mathrm{~cm}$ and typically have bioturbated bottom contacts. In addition to this cyclic lithostratigraphy, there are thin intervals of pinkish and/or whitish coloration due to enrichment of sediment with carbonate clasts, especially conspicuous at $\sim 0.45$ $\mathrm{m}, \sim 1.15 \mathrm{~m}$ and $\sim 2.3 \mathrm{~m}$. This pattern of sequence can be recognized throughout the entire western Arctic Ocean (Phillips and Grantz, 2001; Polyak et al., 2004). Various paleoceanographic proxies measured in this core such as the diffuse spectral reflectance in the visual spectra (exemplified by $\mathrm{L}^{*}$ and $\mathrm{a}^{*}$ channels), the content of sand and coarser fraction $(>63 \mu \mathrm{m})$, and the $\delta^{18} \mathrm{O}$ and $\delta^{13} \mathrm{C}$ in the calcite of planktonic foraminifer Neogloboquadrina pachyderma (sinistral) are reported in Adler et al. (this volume).

Cores were stored at $\sim 5^{\circ} \mathrm{C}$. Samples were taken every $1 \mathrm{~cm}$ from the uppermost $250 \mathrm{~cm}$ of the core and immediately frozen at $-20^{\circ} \mathrm{C}$. Samples were freeze-dried, mixed and split into aliquots. A total of 250 samples was analyzed in this study.

\subsection{Age-depth model}

We used the age-depth model generated by Kaufman et al. (2008) and Adler et al. (this volume). The age-depth model was developed from ten C-14 dates of planktonic foraminifer Neogloboqoadrina pachyderma (sin.) (4.0-44.8 ka), twenty-three dates by the amino-acid racemization rates in $N$. pachyderma ( $\sin$.), six tie points obtained from stratigraphic correlation with ACEX Holes and adjacent cores from the central Lomonosov Ridge (O'Regan et al., 2008), and five tie points obtained from correlation of glacial units with Eurasian glaciations (Svendsen et al., 2004; Larsen et al., 2006). According to this age model, the sequence of the uppermost $250 \mathrm{~cm}$ covers the last ca. $130 \mathrm{ka}$ (MIS-1 to MIS-5e).

\subsection{TOC measurement}

Samples were analyzed for total organic carbon (TOC) using a LECO WR-112 carbon analyzer. The analyzer was attached to a halogen trap (antimony and potassium iodide). To remove carbonate carbon, the sample was acidified as follows: aliquots of ca. $0.5-1 \mathrm{~g}$ were soaked in $1 \mathrm{M} \mathrm{HCl}$ in a ceramic crucible overnight and then heated at $150^{\circ} \mathrm{C}$ for $3 \mathrm{~h}$ after adding more $1 \mathrm{M} \mathrm{HCl}$. The sample was rinsed (x 2) to remove chlorides by adding distilled water and was again heated at $110^{\circ} \mathrm{C}$ for $3 \mathrm{~h}$. The measurement precision was better than 0.01 $\mathrm{wt} \%$.

\subsection{Hydrocarbon analysis}

Lipids were extracted (x 3) from ca. $5 \mathrm{~g}$ of dried sediment using a DIONEX Accelerated Solvent Extractor ASE-200 at $100^{\circ} \mathrm{C}$ and 1000 psi for 10 min with $11 \mathrm{ml}$ of $\mathrm{CH}_{2} \mathrm{Cl}_{2}-\mathrm{CH}_{3} \mathrm{OH}$ (6:4) and then concentrated. The lipid 
extract was separated into four fractions using column chromatography $\left(\mathrm{SiO}_{2}\right.$ with $5 \%$ distilled water; i.d., $5.5 \mathrm{~mm}$; length, $45 \mathrm{~mm}$ ): F1 (hydrocarbons), $3 \mathrm{ml}$ hexane; F2 (aromatic hydrocarbons), $3 \mathrm{ml}$ hexane-toluene (3:1); F3 (ketones), 4 $\mathrm{ml}$ toluene; F4 (polar compounds), $3 \mathrm{ml}$ toluene- $\mathrm{CH}_{3} \mathrm{OH}(3: 1) ; n-\mathrm{C}_{36} \mathrm{H}_{74}$ and $\mathrm{C}_{46}$ GDGT (2,2'-di-O-decyl-3,3'-di-O-(1", $\omega$ '-eicosanyl)-1-1'-di-(rac-glycerol); Patwardhan and Thompson, 1999) were added as internal standards to F1 and F4, respectively.

Gas chromatography (GC) was conducted using a Hewlett Packard 6890 gas chromatograph with on-column injection and a flame ionization detector (FID). Samples were dissolved in hexane. He was the carrier gas and the flow velocity was maintained at $30 \mathrm{~cm} / \mathrm{s}$. A Chrompack CP-Sil5CB column was used (length, $60 \mathrm{~m}$; i.d., $0.25 \mathrm{~mm}$; thickness, $0.25 \mu \mathrm{m}$ ). The oven temperature was programmed to rise from 70 to $130^{\circ} \mathrm{C}$ at $20^{\circ} \mathrm{C} / \mathrm{min}$, from 130 to $310^{\circ} \mathrm{C}$ at $4^{\circ} \mathrm{C} / \mathrm{min}$, and to hold at $310^{\circ} \mathrm{C}$ for $30 \mathrm{~min}$. The standard deviations of five duplicate analyses averaged $7.5 \%$ of the concentration for each compound.

\subsection{Glycerol dialkyl glycerol tetraether (GDGT) analysis}

An aliquot of F4 was dissolved in hexane-2-propanol (99:1). Glycerol dialkyl glycerol tetraethers (GDGTs) were analyzed using high performance liquid chromatography-mass spectrometry (HPLC-MS) with an Agilent 1100 HPLC system connected to a Bruker Daltonics micrOTOF-HS time-of-flight mass spectrometer. Separation was conducted using a Prevail Cyano column $\left(2.1 \times 150 \mathrm{~mm}, 3 \mu \mathrm{m}\right.$; Alltech) and maintained at $30^{\circ} \mathrm{C}$ following the method of Hopmans et al. (2000) and Schouten et al. (2007). Conditions were: flow rate $0.2 \mathrm{ml} / \mathrm{min}$, isocratic with $99 \%$ hexane and 1\% 2-propanol for the first $5 \mathrm{~min}$ followed by a linear gradient to $1.8 \%$ 2-propanol over $45 \mathrm{~min}$. Detection was achieved using atmospheric pressure, positive ion chemical ionization-mass spectrometry (APCI-MS). The spectrometer was run in full scan mode $(\mathrm{m} / \mathrm{z}$ 500-1500). Compounds were identified by comparing mass spectra and retention times with those of GDGT standards (formed from the main phospholipids of Thermoplasma acidophilum via acid hydrolysis) and those in the literature (Hopmans et al., 2000). Quantification was achieved by integrating the summed peak areas in the $(\mathrm{M}+\mathrm{H})^{+}$and the isotopic $(\mathrm{M}+\mathrm{H}+1)^{+}$ion traces and comparing these to the peak area of an internal standard $\left(\mathrm{C}_{46}\right.$ GDGT; Patwardhan and Thompson, 1999) in the $(\mathrm{M}+\mathrm{H})^{+}$ion trace, according to the method of Huguet et al. (2006). The correction value of ionization efficiency between GDGTs and the internal standard was obtained by comparing the peak areas of T. acidophilum-derived mixed GDGTs and $\mathrm{C}_{46}$ GDGT of known amounts. The standard deviation of a replicate analysis is $3.0 \%$ of the concentration for each compound.

\section{Results and discussion}

Typical gas chromatograms of F1 and HPLC-MS chromatograms of F-4 are shown in Figs. 2 and 3, respectively.

\subsection{TOC content}

The TOC content varies between 0.02 and $0.48 \%$, with an average of 
$0.28 \%$. The TOC decreases exponentially with increasing depth (Fig. 4D).

\subsection{Normal-alkane distribution}

$\mathrm{N}$-alkanes occur as a major component of the $\mathrm{F} 1$ (hydrocarbon) fraction and show a unimodal distribution with a maximum at $\mathrm{C}_{25}-\mathrm{C}_{31}$ (Fig. 2). The odd carbon number preference index (CPI) values of $\mathrm{C}_{24}-\mathrm{C}_{34}$ homologues (Bray and Evans, 1961) vary between 1.5 and 5.3, with an average of 4.0 (Fig. 4F). The average chain length (ACL) vales of $\mathrm{C}_{27}-\mathrm{C}_{33}$ homologues (Bray and Evans, 1961) vary between 29.2 and 29.8, with an average of 29.6 (Fig. 4F). Most samples showed n-alkane distribution of mixture of a pattern with high odd carbon number preference (CPI $=\sim 5$; Fig. $2 \mathrm{~A}$ ) and high average chain length $(\mathrm{ACL}=\sim 29.7)$ and a pattern heavily influenced by mature (thermally altered) n-alkane with low CPI ( 1.5; Fig. 2B) and low ACL ( 29.2). The former is typical of terrestrial higher plant waxes (Eglinton and Hamilton, 1967). This pattern indicates that the $\mathrm{OM}$ was derived from fresh higher plant material. The latter is typical of coal and coaly shale (Bray and Evans, 1961), indicating an influx of mature (lithic) OM.

If we assess the end-member CPI values of higher-plant and mature OM, we can estimate the concentrations of $n$-alkanes of both origins. Riverine suspended matter and surficial sediments from the Arctic $\mathrm{Ob}$ and Yenisei Rivers have CPI values from 3.2 to 8.1 (average 5.8; Fernandes and Sicre, 2000). Assuming that the long-chain n-alkanes derived from higher plant waxes have CPI of 5.2 (maximal value for samples in the study core), and those derived from mature rocks have CPI of 1 (typical values of OM in catagenesis and metagenesis stages; Tissot and Welte, 1984), we calculated concentrations of "higher plant" and "lithic" $\mathrm{C}_{25}-\mathrm{C}_{33}$ n-alkanes from total $\mathrm{C}_{25}-\mathrm{C}_{33}$ n-alkane concentration and the $\mathrm{CPI}$ value using the following formulae:

Higher plant $\mathrm{C}_{25}-\mathrm{C}_{33}$ n-alkane $=$ total $\mathrm{C}_{25}-\mathrm{C}_{33}$ n-alkane $\times\{6.2$ $(\mathrm{CPI}-1)\} /\{4.2(\mathrm{CPI}+1)\}$

Lithic $\mathrm{C}_{25}-\mathrm{C}_{33}$ n-alkane $=$ total $\mathrm{C}_{25}-\mathrm{C}_{33}$ n-alkane - higher plant $\mathrm{C}_{25}-\mathrm{C}_{33}$ n-alkane

"Higher plant" n-alkane concentration varies with sediment color approximated by $\mathrm{L}^{*}$ (lightness); Higher concentrations are found in high $\mathrm{L}^{*}$ intervals (grayish layers), which also have lighter oxygen isotopic composition of planktonic foraminiferal calcite (Figs. 4B and 4E). In contrast, "lithic" n-alkane concentration is not synchronized with $\mathrm{L}^{*}$ (Figs. 4B and 4E).

\subsection{GDGT distribution}

HPLC-MS revealed that GDGTs are a major high-molecular-weight component of the F4 and comprise both isoprenoid and branched components. The isoprenoid GDGTs include cardarchaeol, GDGT-1, GDGT-2, crenarchaeol, and crenarchaeol regioisomer (Fig. 3). Caldarchaeol and crenarchaeol are relatively abundant in isoprenoid GDGTs. Branched GDGTs make up a homologous series with four to six methyl groups (Hopmans et al., 2004; Fig. $3)$. 
Branched GDGTs are presumably derived from anaerobic bacteria and occur widely in soils and peat bogs (Weijers et al., 2006a). Isoprenoid GDGTs are not source specific because they derive from both marine and terrestrial Archaea (Nishihara et al., 1997; Sinninghe Damsté, 2002b). Crenarchaeol in marine sediments was thought to be derived solely from pelagic crenarchaeota (Sinninghe Damsté et al., 2002b). Microbiological studies have demonstrated the presence of marine crenarchaeota in Arctic waters (Bano et al., 2004). Weijers et al. (2006b) recently found crenarchaeol in soil samples. The crenarchaeol found in our samples is associated with abundant branched GDGTs, suggesting possible contribution of soil crenarchaeota. It is thus likely that crenarchaeol in the study samples has a mixed origin of soil crenarchaeota and aquatic crenarchaeota.

Concentrations of both branched and isoprenoid GDGTs exponentially decrease with increasing depth (Fig. 4G). This decreasing trend is attributed to degradation of GDGTs during early diagenesis. Superimposed on this general decreasing trend, the concentrations show a significant fluctuation that corresponds to $\mathrm{L}^{*}$ variation (Fig. 4G). The concentration maxima occur in higher $\mathrm{L}^{*}$ intervals (grayish layers).

Hopmans et al. (2004) defined the Branched and Isoprenoid Tetraether (BIT) index as the ratio of branched GDGTs to the sum of branched GDGTs and crenarchaeol as an index of soil OM contribution. BIT ranges from $\sim 0.46$ to 0.93 with the average of 0.73 (Fig. $4 \mathrm{H}$ ). The range of values is similar to that in the central Arctic Ocean ( 0.5-1; Yamamoto et al., 2008), but is anomalously high for normal pelagic marine sediments. The high BIT index in the western Arctic Ocean reflects a significant contribution of terrestrial soil OM. Yamamoto et al. (2008) reported that major biomarkers in central Arctic sediments (Site M4, Fig. 1) are long-chain n-alkanes, n-fatty acids and n-alkan-1-ols, indicating terrestrial $\mathrm{OM}$ input. The dominance of terrestrial biomarkers was attributed to severe $\mathrm{OM}$ degradation caused by slow sedimentation in oxygen-rich benthic water and/or low primary production due to permanent sea ice coverage (Yamamoto et al., 2008). The dominance of long-chain n-alkanes and high BIT in Core HLY0503-08JPC is consistent with these earlier observations in the central Arctic Ocean, suggesting that the environment of the study site has been under similar conditions. Low BIT corresponds to low L* (brown layers), indicating higher contribution of crenarchaeol that derived solely from crenarchaeota, which might have affected by the contribution of marine crenarchaota living in shelf and/or pelagic water.

\subsection{Degradation of OM during early diagenesis}

Bottom sediments in the central Arctic Ocean are well oxygenated, as demonstrated on the ACEX core from the Lomonosov Ridge (Backman et al., 2006). The pore water chemistry indicates that manganese oxide reduction occurs between 1.5 and $80 \mathrm{~m}$ below sea floor, iron oxide reduction occurs between 20 and $200 \mathrm{~m}$ below sea floor, and sulfate reduction starts below $200 \mathrm{~m}$ below sea floor (Backman et al., 2006). We infer that similar oxidative environments characterize Core HLY0503-08JPC, which is stratigraphically and sedimentologically comparable to cores from the Lomonosov Ridge (Adler et al., 
this volume). The oxygenated sediments are ideal for evaluating the degradation rates of organic compounds with time. The general decreasing trends of TOC, $\mathrm{C}_{25}-\mathrm{C}_{33}$ n-alkanes, isoprenoid GDGTs, and branched GDGTs with increasing depth and age are attributed to the degradation of OM during early diagenesis (Fig. 5). We calculated the first-order decomposition rate constants $\left(k\left[\mathrm{yr}^{-1}\right]\right)$ and initial concentrations $\left(\mathrm{C}_{0}\right)$ by fitting concentrations $\left(\mathrm{C}_{\mathrm{t}}\right)$ versus sample ages $(\mathrm{t}$ $\left.\left[\mathrm{yr}^{-1}\right]\right)$ to the following equation:

$$
\mathrm{C}_{\mathrm{t}}=\mathrm{C}_{0} \mathrm{e}^{-\mathrm{kt}}
$$

The calculated values of first-order decomposition rate constant $\left(k\left[\mathrm{yr}^{-1}\right]\right)$ and initial concentration $\left(\mathrm{C}_{0}\right)$ are shown in Table 1 . The $k$ values of branched GDGTs $\left(2.0 \times 10^{-5} \mathrm{yr}^{-1}\right)$ and isoprenoid GDGTs $\left(2.5 \times 10^{-5} \mathrm{yr}^{-1}\right)$ are higher than those of TOC $\left(1.1 \times 10^{-5} \mathrm{yr}^{-1}\right)$ and $\mathrm{C}_{25}-\mathrm{C}_{33}$ n-alkanes $\left(1.0 \times 10^{-5} \mathrm{yr}^{-1}\right)$. Long-chain n-alkanes are as stable as TOC, being consistent with previous observations (Prahl et al., 1997; Sinninghe Damsté et al., 2002a). GDGTs are relatively less stable than TOC and long-chain n-alkanes in oxygenated conditions.

\subsection{Changes in the source of OM in glacial and interglacial regimes}

Sediments of Core HLY0503-08JPC are characterized by a distinct alteration of brown and yellowish-gray layers interpreted as interglacial/interstadial and glacial/stadial environments, respectively (e.g., Jakobsson et al., 2000; Polyak et al., 2004; Adler et al., this volume). This study shows that grayish layers are characterized by abundant higher plant n-alkanes and branched GDGTs (Figs. 4E and 4G), suggesting that the OM derived from higher plants and soil is more abundant in these layers than brown layers. The concentrations of higher plant n-alkanes and branched GDGTs are the functions of (1) preservation degree of the compounds, (2) climates of source region, (3) transportation mechanisms, and (4) transportation pathway.

Brown layers are thought to be deposited under the conditions of well ventilated intermediate and bottom waters (Jakobsson et al., 2000; Polyak et al., 2004). The resulting oxygenated condition generally enhances the degradation of OM, thus reducing the concentration of organic compounds. In the study core, variation in TOC did not correspond to brown/gray cycles. Because the first-order decomposition rate constant of TOC $\left(1.1 \times 10^{-5} \mathrm{yr}^{-1}\right)$ is the same order of that of $\mathrm{C}_{25}-\mathrm{C}_{33}$ n-alkanes $\left(1.0 \times 10^{-5} \mathrm{yr}^{-1}\right.$; Table 1), little correspondence of TOC to brown/gray cycles implies that changes in redox conditions are not the principal factor regulating the concentrations of $\mathrm{C}_{25}-\mathrm{C}_{33} \mathrm{n}$-alkanes.

The OM derived from higher plants and soil is more abundant in grayish layers deposited in glacials/stadials. The production of higher plants is generally higher in warmer and wetter climates (Whittakker et al., 1970). The concentration of branched GDGTs in soil has positive correlation with mean annual temperature and also has negative correlation with the soil $\mathrm{pH}$ (Weijers et al., 2006a), implying that the production of branched GDGTs are higher in warmer and wetter climates. However, higher concentration of branched GDGTs in the Arctic cores occurs in glacial/stadial rather than interglacial/interstadial intervals. Thus, the larger contribution of higher plant and soil OM in the study 
samples does not reflect climates of source regions, but more efficient transportation of OM from land to the Arctic Ocean.

Concentrations of higher plant n-alkanes and branched GDGTs in grayish layers are not related with the content of coarse fraction ( $>63 \mu \mathrm{m}$; Figs. $4 \mathrm{C}, 4 \mathrm{E}$, and 4G). This suggests that higher plant and soil OM were transported not with coarse particles, but rather with fine particles either by sea ice rafting or subsurface water currents. Fine, muddy sediment in the central part of grayish layers suggests negligible contribution from ice rafting, probably due to the solidly ice-bound ocean surface (Polyak et al., 2004; Adler et al., this volume). Polyak et al. (this volume) suggest that the major source of this sediment was glacial flour delivered by meltwater from glaciated margins at the Arctic Ocean periphery. Abundance of higher plant n-alkanes and branched GDGTs in grayish layers is thus related to the deposition of fine-grained products of glacial erosion. The peat that was deposited in northern North America and Eurasia during interglacials is a potential source of higher plant and soil OM. Ice erosion of peat during glacials could deliver such an $\mathrm{OM}$ into the Amerasian Basin. Because this hypothesis is still speculative, we need further provenance studies to clarify the source and transportation mechanisms of OM.

\subsection{Intermittent transport of mature OM by icebergs and sea ices}

Concentration of lithic n-alkanes and the relative abundance of lithic $\mathrm{n}$-alkanes in total $\mathrm{n}$-alkanes (reflected as CPI reversely) show sixteen maxima in the uppermost $250 \mathrm{~cm}$ of the study core (Fig. 6). Ten of sixteen peaks occur at the boundary between grayish and brown layers (Fig. 6). Eight of sixteen peaks have maximal peaks of the content of coarse fraction $(>63 \mu \mathrm{m})$. Another series of eleven peaks have minimal peaks of ACL. Based on associated peaks of coarse fraction $(>63 \mu \mathrm{m})$, detrital carbonate layers and ACL, the maximal peaks of lithic n-alkanes are classified into six different types (Types A-F in Fig. 6).

The peaks of type A are associated with maximal sand content and occur at or close to detrital carbonate layers. Because the only source of this detrital carbonate (mostly dolomite) in the central Arctic Ocean is derived from the Laurentide part of the Canadian Archipelago (Bischof et al., 1996; Darby et al., 2002), this type may have derived by icebergs from the same source.

The peaks of type B are associated with minimal ACL and high content of coarse fraction $(>63 \mu \mathrm{m})$. The peak at $247.5 \mathrm{~cm}$ in depth belonging to this type correlates to a major peak of iron oxide grains derived from the Innuitian ice sheet in NP26 cores (Polyak et al., 2004). This correspondence suggests that this type might have derived by icebergs from the Innuitian ice sheet.

The peak of type $\mathrm{C}$ is associated with a strong minimum in ACL and a maximal content of coarse fraction $(>63 \mu \mathrm{m})$ and correlates to a major peak of quartz IRD and iron oxide grains attributed to Barents and Kara sources in NP26 cores (Polyak et al., 2004). The stratigraphic position of this peak corresponds to a large glaciation in northern Eurasia associated with freshwater discharge from large ice-dammed lakes at $\sim 75 \mathrm{ka}$ (Spielhagen et al., 2004).

The peaks of type D are associated with strong minima in ACL. The peak at $215.5 \mathrm{~cm}$ in depth belonging to this type correlates to a major peak of iron oxide grains attributed to the Laptev and East Siberian seas in NP26 cores 
(Polyak et al., 2004), suggesting northern Siberian origin.

The peaks of type $\mathrm{E}$ are associated with moderate minima in ACL. The peak at $66.5 \mathrm{~cm}$ in depth is associated with a $\delta^{18} \mathrm{O}$ depletion of planktonic foraminifer (Figs $4 \mathrm{~B}$ and $4 \mathrm{~F}$ ), which is attributed to a voluminous pulsed meltwater discharge (Adler et al., this volume). The peaks at 128.5 and $141.5 \mathrm{~cm}$ in depth correlate to major peaks of iron oxide grains attributed to the Barents and Kara seas in NP26 cores, and the peak at $172.5 \mathrm{~cm}$ in depth correlates to that of the Laptev and East Siberian seas (Polyak et al., 2004), suggesting northern Siberian origin.

The peak of type $\mathrm{F}$ is associated with a non-carbonaceous IRD spike. The stratigraphic position of this peak corresponds to a large glaciation in northern Eurasia associated with freshwater discharge from large ice-dammed lakes at $\sim 52 \mathrm{ka}$ (Spielhagen et al., 2004).

Preliminary correlation between the types of lithic OM peaks in the study core and the types of iron oxide grains in NP26 cores suggests that the type of lithic OM is also useful for identifying the sediment source. Future studies such as a more detailed finger-print analysis for trace biomarkers and a comparison with the composition of iron oxide grains have a potential for refining the provenance of the Arctic Ocean sediments.

Some of minimal peaks of CPI at the boundary between gray and brown layers show a saw-tooth changing pattern of CPI; the sudden drops of CPI and the subsequent gradual increases (Fig. 6). This implies that mature OM was massively delivered at the initial stage of each event and was gradually replaced by higher plant and soil OM. Spielhagen et al. (2004, 2005) and Jakobsson et al. (2007) suggested that the outburst of the water from ice dammed lakes in Siberia occurred several times during the Late Pleistocene. Similar events may have taken place on the North American side, but they are less understood except for the last deglaciation (Poore et al., 1999; Polyak et al., 2007). Such an outburst combined with a massive iceberg discharge could have eroded bedrocks including coals and coaly shales and discharged mature OM onto the continental shelf. After that, gradual supply of higher plant and soil OM by rivers could dilute mature OM preserved on the shelf. This mechanism could change the composition of OM in the source area from lithic to higher plant and soil OM.

\section{Conclusions}

Biomarker records from western Arctic Ocean sediments show drastic changes with glacial-interglacial variation. Concentrations of higher plant-derived compounds, thermally altered compounds, and soil-derived compounds are highly sensitive to past changes in sediment delivery mechanisms and source areas.

Variations in long-chain n-alkane and GDGT concentrations indicate higher contribution of terrestrial OM (higher plant and soil OM) during glacials/stadials. these changes in the source of OM are presumably related to the enhanced delivery of the products of glacial erosion including higher plant and soil OM from the glaciated margins into the Amerasian basin.

Concentration maxima of lithic n-alkanes derived from mature OM may correspond to events of iceberg discharge and freshwater outburst from 
proglacial lakes that carried eroded bedrock material.

\section{Acknowledgements}

We thank members of HOTRAX'05 for collecting HLY0503-8JPC core. We also thank Hirotaka Sai, Takahiro Nakanishi, Norio Ichikawa, Masahiro Ushio, Mayumi Nakata, Tatsufumi Okino, Masao Minagawa (Hokkaido University) for help with analysis. Special thanks are due to Dennis A. Darby (Old Dominim University) and two anonymous reviewers for improving the manuscript. This study was supported by a grant-in-aid for Scientific Research (A) the Japan Society for the Promotion of Science, No. 19204051 (to MY).

\section{References}

Aagaard, K., Carmack, E.C., 1989. The role of sea ice and other fresh water in the Arctic circulation. Journal of Geophysical Research 94, 14485-14498.

Adler, R., Polyak, L., Ortiz, J., Kaufman, D., Channell, J., Xuan, C., Fornaciari, E., Grottoli, A., Sellen, E., in review. The first sediment record of Late Quaternary environments in the western Arctic Ocean with a true millennial resolution: HOTRAX core HLY0503-8JPC, Mendeleev Ridge. Global and Planetary Change, this volume.

Backman, J., Moran, K., McInroy, D.B., Mayer, L.A., the Expedition 302 Scientists, 2006. Proceedings of Integrated Ocean Drilling Program, 302. Integrated Ocean Drilling Program Management International, Inc., Edinburgh, doi:10.2204/iodp.proc.302.2006

Bano, N., Ruffin, S, Ransom, B., Hollibaugh, J.T., 2004. Phylogenetic composition of Arctic Ocean Archaeal assemblages and comparison with Antarctic assemblages. Applied and Environmental Microbiology 70, 781-789.

Belicka, L.L., Macdonald, R.W., Harvey, H.R., 2002. Sources and transport of organic carbon to shelf, slope, and basin surface sediments of the Arctic Ocean. Deep-Sea Research I 49, 1463-1483.

Belicka, L.L., Macdonald, R.W., Yunker, M.B., Harvey, H.R., 2004. The role of depositional regime on carbon transport and preservation in Arctic Ocean sediments. Marine Chemistry 86, 65-88.

Bischof, J.A., Darby, D.A., 1997. Mid to Late Pleistocene ice drift in the western Arctic Ocean: evidence for a different circulation in the past. Science 277, 74-78.

Bischof, J.F., Clark, D.L., Vincent, J.S., 1996. Pleistocene paleoceanography of the central Arctic Ocean: the sources of ice rafted debris and the compressed sedimentary record. Paleoceanography 11, 743-756.

Bouscein, B., Knies, J., Stein, R., 2002. Organic matter deposition along the Kara and Laptev Seas continental margin (eastern Arctic Ocean) during the last deglaciation and Holocene: evidence from organic-geochemical and petrographic data. Marine Geology 183, 67-87.

Bray, E.E., Evans, E.D., 1961. Distribution of n-paraffins as a clue to recognition of source beds. Geochimica et Cosmochimica Acta 22, 2-15.

Clark, D.L., Whitman, R.R., Morgan, K.A., Mackey, S.D., 1980. Stratigraphy and glacial-marine sediments of the Amerasian Basin, central Arctic Ocean. 
Geological Society of America, Special Paper 181, 57 pp.

Darby, D.A., Bischof, J.F., Jones, G.A., 1997. Radiocarbon chronology of depositional regimes in the western Arctic Ocean. Deep-Sea Research II 44, 1745-1757.

Darby, D.A., Bischop, J.F., Spielhagen, R.F., Marshall, S.A., Herman, S.W., 2002. Arctic ice export events and their potential impact on global climate during the late Pleistocene. Paleoceanography 17, 15-1-17.

Darby, D., Jakobsson, M., Polyak, L., 2005. Icebreaker expedition collects key Arctic seafloor and ice data. EOS Transaction, AGU, 86(52), 549-556.

Delworth, T.L.S., Manabe, S., Stouffer, R.J., 1997. Multidecadal climate variability in the Greenland Sea and surrounding regions: a coupled simulation. Geophysical Research Letters 24, 257-260.

Eglinton, G., Hamilton, R.J., 1967. Leaf epicuticular waxes. Science 156, 1322-1355.

Fahl, K., Stein, R., 1997. Modern organic carbon deposition in the Laptev Sea and the adjacent continental slope: surface water productivity vs. terrigenous input. Organic Geochemistry 26, 379-390.

Fahl, K., Stein, R., 1999. Biomarkers as organic-carbon-source and environmental indicators in the Late Quaternary Arctic Ocean: problems and perspectives. Marine Chemistry 63, 293-309.

Fernandes, M.B., Sicre, M.-A., 2000. The importance of terrestrial organic carbon inputs on Kara Sea shelves as revealed by n-alkanes, OC and d13C values. Organic Geochemistry 31, 363-374.

Gordienko, P.A., Laktionov, A.F., 1969. Circulation and physics of the Arctic Basin waters. Annals of International Geophysical Year, Oceanography 46, 94-112.

Hopmans, E.C., Schouten, S., Pancost, R., van der Meer, M.T.J., Sinninghe Damsté, J.S., 2000. Analysis of intact tetraether lipids in archaeal cell material and sediments by high performance liquid chromatography/atmospheric pressure chemical ionization mass spectrometry. Rapid Communications in Mass Spectrometry 14, 585-589.

Hopmans, E.C., Weijers, J.W.H., Schefuß, E., Herfort, L., Sinninghe Damsté, J.S., Schouten, S., 2004. A novel proxy for terrestrial organic matter in sediments normalized on branched and isoprenoid tetraether lipids. Earth and Planetary Science Letters 224, 107-116.

Huguet, C., Hopmans, E.C., Febo-Ayala, W., Thompson, D.H, Sinninghe Damste, J.S., Schouten, S., 2006. An improved method to determine the absolute abundance of glycerol dibiphytanyl glycerol tetraether lipids. Organic Geochemistry 37, 1036-1041

Jakobsson, M., Løvlie, R., Al-Hanbali, H., Arnold, E., Backman, J., Mörth, M., 2000. Manganese/color cycles in Arctic Ocean sediments constrain Pleistocene chronology. Geology 28, 23-26.

Jakobsson, M., Björck, S., Alm, G., Andrén, T., Lindeberg, G., Svensson, N.-O., 2007. Reconstructing the Younger Dryas ice dammed lake in the Baltic Basin: Bathymetry, area and volume. Global and Planetary Change 57, 355 370.

Kaufman, D.S., Polyak, L., Adler, R., Channell, J.E.T., Xuan, C., 2008. Dating 
late Quaternary planktonic 1 foraminifer Neogloboquadrina pachyderma from the Arctic Ocean by using amino acid racemization. Paleoceanography, in press.

Larsen, E., Kjær, K.H., Demidov, I.N., Funder, S., Grøsfjeld, K., Houmark-Nielsen, M., Jensen, M., Linge, H., Lysa, A., 2006. Late Pleistocene glacial and lake history of northwestern Russia. Boreas 35, 394-424.

Nishihara, M., Horii, H., Koga, Y., 1987. Structure determination of a quartet of novel tetraether lipids from Methanobacterium thermoautotrophicum. Journal of Biochemistry 101, 1007-1015.

Nürnberg, D., Wollenburg, I., Dethleff, D., Eicken, H. Kassens, H., Letzig, T., Reimnitz, E., Thiede, J., 1994. Sediments in Arctic sea ice: Implications for entrainment, transport and release. Marine Geology 119, 185-214.

O’Regan, M., King, J., Backman, J., Jakobsson, M., Pälike, H., Moran, K., Heil, C., Sakamoto, T., Cronin, T., Jordan, R.W., 2008. Constraints on the Plio-Pleistocene Chronology of Sediments from the Lomonosov Ridge. Paleoceanography 23, PA1S19.

Patwardhan, A.P., Thompson, D.H., 1999. Efficient synthesis of 40-and 48-membered tetraether macrocyclic bisphosphocholines. Organic Letters 1, 241-243.

Peulvé, S., Sicre, M.-A., Saliot, A, de Leeuw, J.W., Baas, M., 1996. Molecular characterization of suspended and sedimentary organic matter in an Arctic delta. Limnology and Oceanography 41, 488-497.

Phillips, R.L., Grantz, A., 2001. Regional variations in provenance and abundance of ice-rafted clasts in Arctic Ocean sediments: implications for the configuration of late Quaternary oceanic and atmospheric circulation in the Arctic. Marine Geology 172, 91-115.

Polyak, L., Curry, W.B., Darby, D.A., Bischof, J., Cronin, T.M., 2004. Contrasting glacial/interglacial regimes in the western Arctic Ocean as exemplified by a sedimentary record from the Mendeleev Ridge. Palaeogeography, Palaeoclimatology, Palaeoecology 203, 73-93.

Polyak, L., Darby, D.A., Bischof, J., Jakobsson, M., 2007. Stratigraphic constraints on late Pleistocene glacial erosion and deglaciation of the Chukchi margin, Arctic Ocean. Quaternary Research 67, 234-245.

Polyak, L., Bischof, J., Ortiz, J., Darby, D., Channell, J., Xuan, C., Kaufman, D., Lovlie, R., Schneider, D., Adler, R., in review. Late Quaternary stratigraphy and sedimentation patterns in the western Arctic Ocean. Global and Planetary Change, this volume.

Poore, R.Z., Osterman, L., Curry, W.B., Phillips, R.L., 1999. Late Pleistocene and Holocene meltwater events in the western Arctic Ocean. Geology 27, 759-762.

Prahl, F.G., de Lange, G.J., Sholten, S., Cowie, G.L., 1997. A case of post-depositional aerobic degradation of terrestrial organic matter in turbidite deposits from the Madeira Abyssal Plain. Organic Geochemistry 27, 141-152.

Schouten, S, Hudget, C., Hopmans, E.C., Kienhuis, M.V.M., Sinninghe Damsté, J.S., 2007. Analytical methodology for $\mathrm{TEX}_{86}$ paleothermometry by high performance liquid chromatography/atmospheric pressure chemical 
ionization-mass spectrometry. Analytical Chemistry 79, 2940-2944.

Schubert, C.J., Stein, R., 1996. Deposition of organic carbon in Arctic sediments: terrigenous supply vs marine productivity. Organic Geochemistry 24, 421-436.

Schubert, C.J., Stein, R., 1997. Lipid distribution in surface sediments from the eastern central Arctic Ocean. Marine Geology 138, 11-25.

Sinninghe Damsté, J.S., Rijpstra, W.I., Reichart, G.-J., 2002a. The influence of oxic degradation on the sedimentary biomarker record II. Evidence from Arabian Sea sediments. Geochimica et Cosmochimica Acta 66, 2737-2754.

Sinninghe Damsté, J.S., Schouten, S., Hopmans, E.C., van Duin, A.C.T., Geenevasen, J.A.J., 2002b. Crenarchaeol: the characteristic core glycerol dibiphytanyl glycerol tetraether membrane lipid of cosmopolitan pelagic crenarchaeota. Journal of Lipid Research 43, 1641-1651.

Smith, L.M., Miller, G.H., Otto-Bliesner, B., Shin, S., 2002. Sensitivity of the Northern Hemisphere climate system to extreme changes in Holocene Arctic sea ice. Quaternary Science Reviews 22, 645-658.

Spielhagen, R.F., Baumann, K.-H., Erlenkeuser, H., Nowaczyk, N.R., Nørgaard-Pedersen, N., Vogt, C., Weiel, D., 2004. Arctic Ocean deep-sea record of northern Eurasian ice sheet history. Quaternary Science Reviews 23, 1455-1483.

Spielhagen, R.F., Erlenkeuser, H., Siegert, C., 2005. History of freshwater runoff across the Laptev Sea (Arctic) during the last deglaciation. Global and Planetary Change 48, 187-207.

Stein, R., Grobe, H., Wahsner, M., 1994. Organic carbon, carbonate, and clay mineral distributions in eastern central Arctic Ocean surface sediments. Marine Geology 119, 269-285.

Stein, R., Boucsein, B., Fahl, K., de Oteyza, T.G., Niessen, K.F., 2001. Accumulation of particulate organic carbon at the Eurasian continental margin during late Quaternary times: controlling mechanisms and paleoenvironmental significance. Global and Planetary Change 31, 87-104.

Stein, R., Dittmers, K., Fahl, K., Kraus, M., Matthiessen, J., Niessen, F., Pirrung, M., Polyakova, Y., Schoster, F., Steinke, T., Fütterer, D.K., 2004. Arctic (paleo) river discharge and environmental change: evidence from the Holocene Kara Sea sedimentary record. Quaternary Science Reviews 23, 1485-1511.

Svendsen, J.I., Alexanderson, H., Astakhov, V.I., Demidov, I., Dowdeswell, J.A., et al., 2004. Late Quaternary ice sheet history of northern Eurasia. Quaternary Science Reviews 23, 1229-1271.

Tissot, B.P. and Welte, D.H., 1984. Petroleum Formation and Occurrence, 2nd. ed., Springer-Verlag, Berlin.

Weijers, J.W.H., Schouten, S., Hopmans, E.C., Geenevasen, J.A.J., David, O.R.P., Coleman, J.M., Pancost, R.D., Sinninghe Damsté, J.S., 2006a. Membrane lipids of mesophilic anaerobic bacteria thriving in peats have typical archaeal traits. Environmental Microbiology 8, 648-657.

Weijers, J.W.H., Schouten, S., Spaargaren, O.C., Sinninghe Damsté, J.S., $2006 b$. Occurrence and distribution of tetraether membrane lipids in soils: Implications for the use of the $\mathrm{TEX}_{86}$ proxy and the BIT index. Organic 
Geochemistry 37, 1680-1693.

Whittacker, R.H., 1970. Communities and Ecosystems. The Macmillan, New York.

Yamamoto, M., Okino, T., Sugisaki, S., Sakamoto, T., 2008. Late Pleistocene changes in terrestrial biomarkers in sediments from the central Arctic Ocean. Organic Geochemistry 39, 754-763.

Yunker, M.B., Macdonald, R.W., Veltkamp, D.J., Cretney, W.J., 1995. Terrestrial and marine biomarkers in a seasonally ice-covered Arctic estuary integration of multivariate and biomarker approaches. Marine Chemistry 49, $1-50$.

Yunker, M.B., Belicka, L.L., Harvey, H.R., Macdonald, R.W., 2005. Tracing the inputs and fate of marine and terrigenous organic matter in Arctic Ocean sediments: A multivariate analysis of lipid biomarkers. Deep-Sea Research II 52, 3478-3508.

Zegouagh, Y., Derenne, S., Largeau, C., Saliot, A., 1996. Organic matter sources and early diagenetic alterations in Arctic surface sediments (Lena River delta and Laptev Sea, Eastern Siberia)-I. Analysis of the carboxylic acids released via sequential treatments. Organic Geochemistry 24, 841-857. 
Table 1. First-order decomposition rate constants $(k)$ and initial concentrations $\left(\mathrm{C}_{0}\right)$ of TOC, long-chain n-alkanes, and isoprenoid and branched GDGTs

\begin{tabular}{ccc}
\hline & $\mathrm{C}_{0}$ & $k\left(10^{-5} \mathrm{yr}^{-1}\right)$ \\
\hline TOC & $0.34 \%$ & 1.1 \\
$\mathrm{C}_{25}-\mathrm{C}_{33}$ n-alkanes & $2.0 \mu \mathrm{g} / \mathrm{g}$ & 1.0 \\
Isoprenoid GDGTs & $17.8 \mathrm{ng} / \mathrm{g}$ & 2.5 \\
Branched GDGTs & $11.5 \mathrm{ng} / \mathrm{g}$ & 2.0 \\
\hline
\end{tabular}


Figure captions

Fig. 1. Locations of study site (8JPC; Darby et al., 2005) and ACEX site (M4; Backman et al., 2006) and the bathymetry and surface currents of the Arctic Ocean.

Fig. 2. Gas chromatograms of F1 in samples at (A) $1-2 \mathrm{~cm}$ (B) $141-142 \mathrm{~cm}$. Numbers indicate carbon numbers of $\mathrm{n}$-alkanes. IS is an internal standard $\left(\mathrm{n}-\mathrm{C}_{36} \mathrm{H}_{74}\right)$.

Fig. 3. The HPLC-MS base peak of tetraether lipids in the F4 fraction of sample at $1-2 \mathrm{~cm}$.

Fig. 4. Depth variations in (A) age (Kaufman et al., 2008; Adler et al., this volume), (B) color reflectance $\mathrm{L}^{*}$ and $\delta^{18} \mathrm{O}$ of $150-250 \mu \mathrm{m}$ planktonic foraminifera $N$. pachyderma (sin.) (Adler et al., this volume), (C) content of sand and coarser fraction ( $>63 \mu \mathrm{m}$ particles; Adler et al., this volume), (D) total organic carbon (TOC) content, (F) concentrations of total, and higher plant long-chain $\mathrm{C}_{25}-\mathrm{C}_{33} n$-alkanes, $(\mathrm{F})$ carbon number preference index $(\mathrm{CPI})$ and average chain length (ACL) of $\mathrm{C}_{27}-\mathrm{C}_{33} n$-alkanes, $(\mathrm{G})$ concentrations of branched and isoprenoid GDGTs, and $(\mathrm{H})$ the branched and isoprenoid tetraether (BIT) and the ratio of caldarchaeol to crenarchaeol (Cald/Cren) in Core FLY0503-08JPC. Shades indicate brown sediment layers; dark shades show the most conspicuous detrital carbonate layers. Brown and grayish units are indexed as in Polyak et al. (2004).

Fig.5. Age variations in TOC content, long-chain $\mathrm{C}_{25}-\mathrm{C}_{33} n$-alkane concentration, and concentrations of branched and isoprenoid GDGTs in Core HLY0503-08JPC.

Fig. 6. Depth variations in color reflectance $L^{*}$ and the content of sand and coarser fraction ( $>63 \mu \mathrm{m}$ particles) (Adler et al., this volume), lithic long-chain $\mathrm{C}_{25}-\mathrm{C}_{33} n$-alkane concentration, and CPI and ACL of $\mathrm{C}_{27}-\mathrm{C}_{33} n$-alkanes in Core HLY0503-08JPC. Letters of A-F indicate the types of peak. Single star and double stars indicate moderate and strong peaks, respectively. 


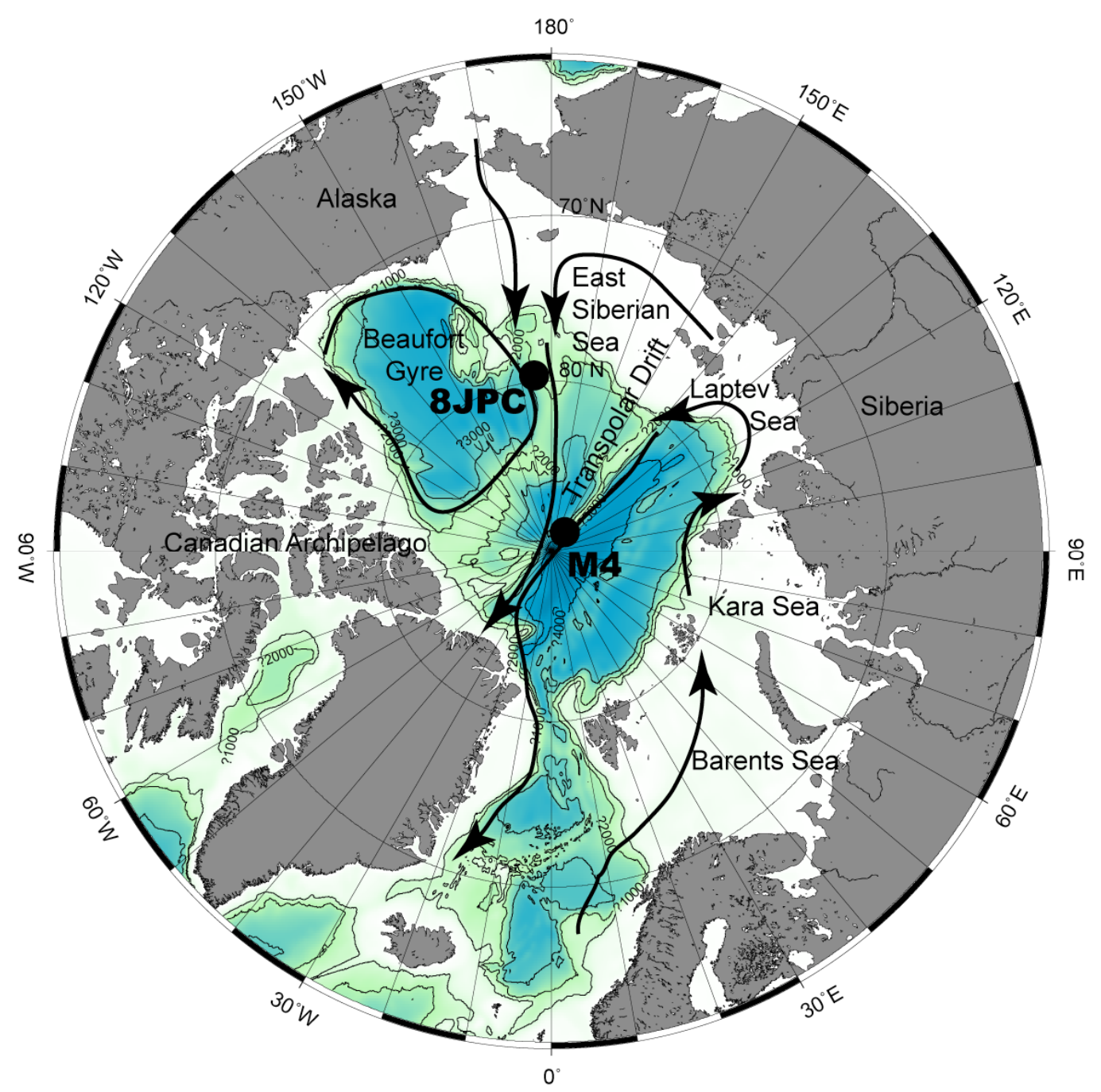

Fig. 1 

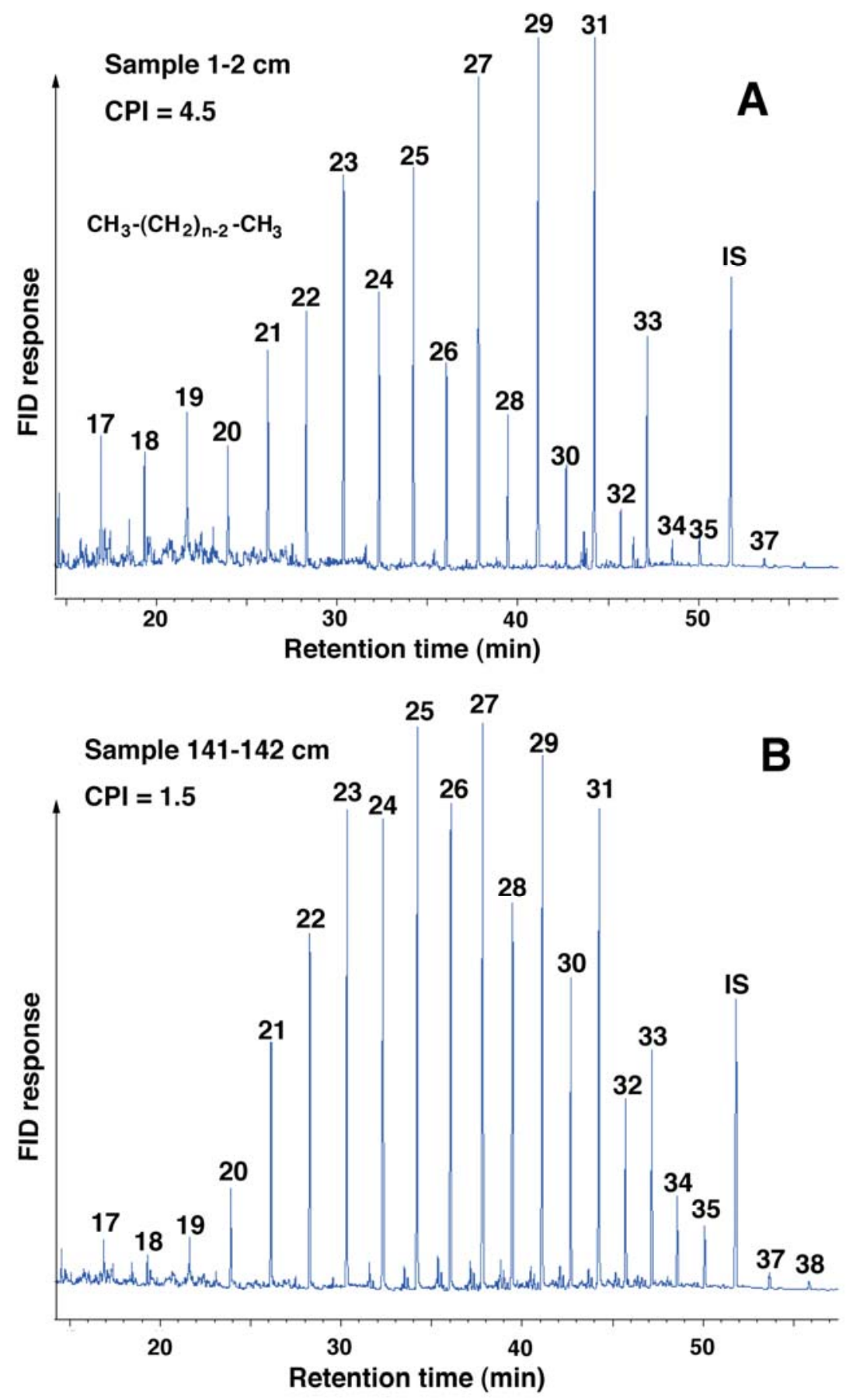

Fig. 2 


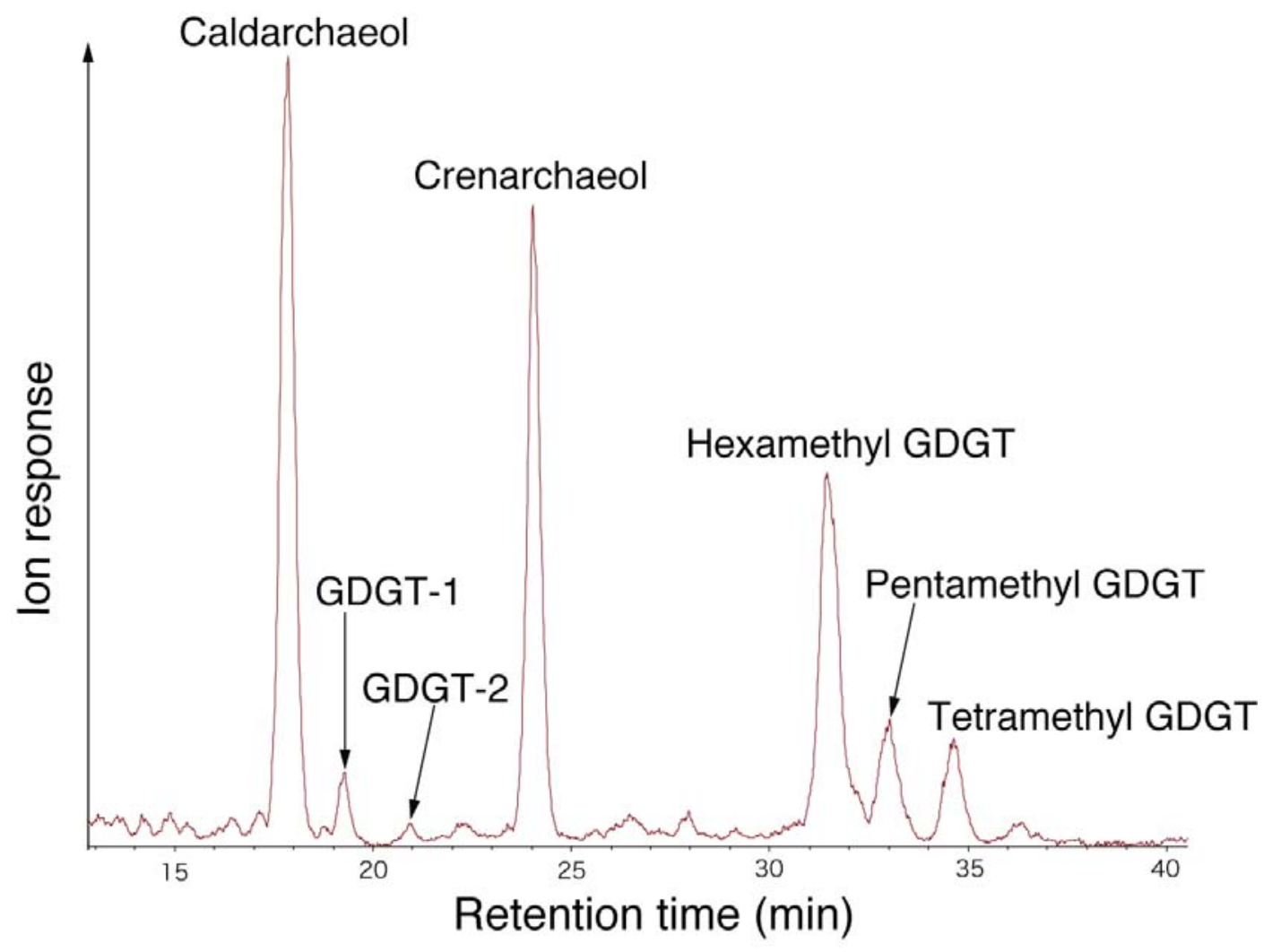

Fig. 3 

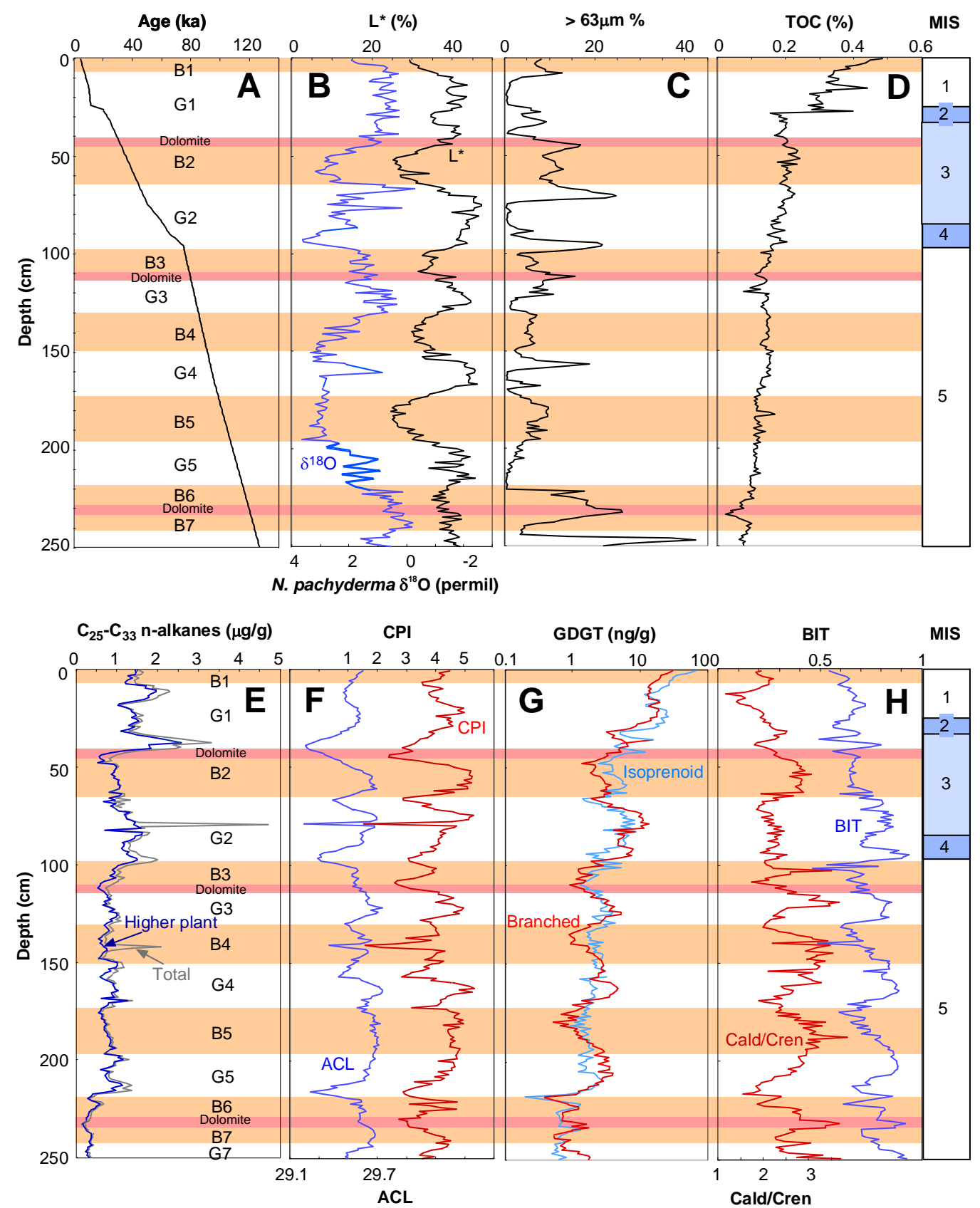

Fig. 4 

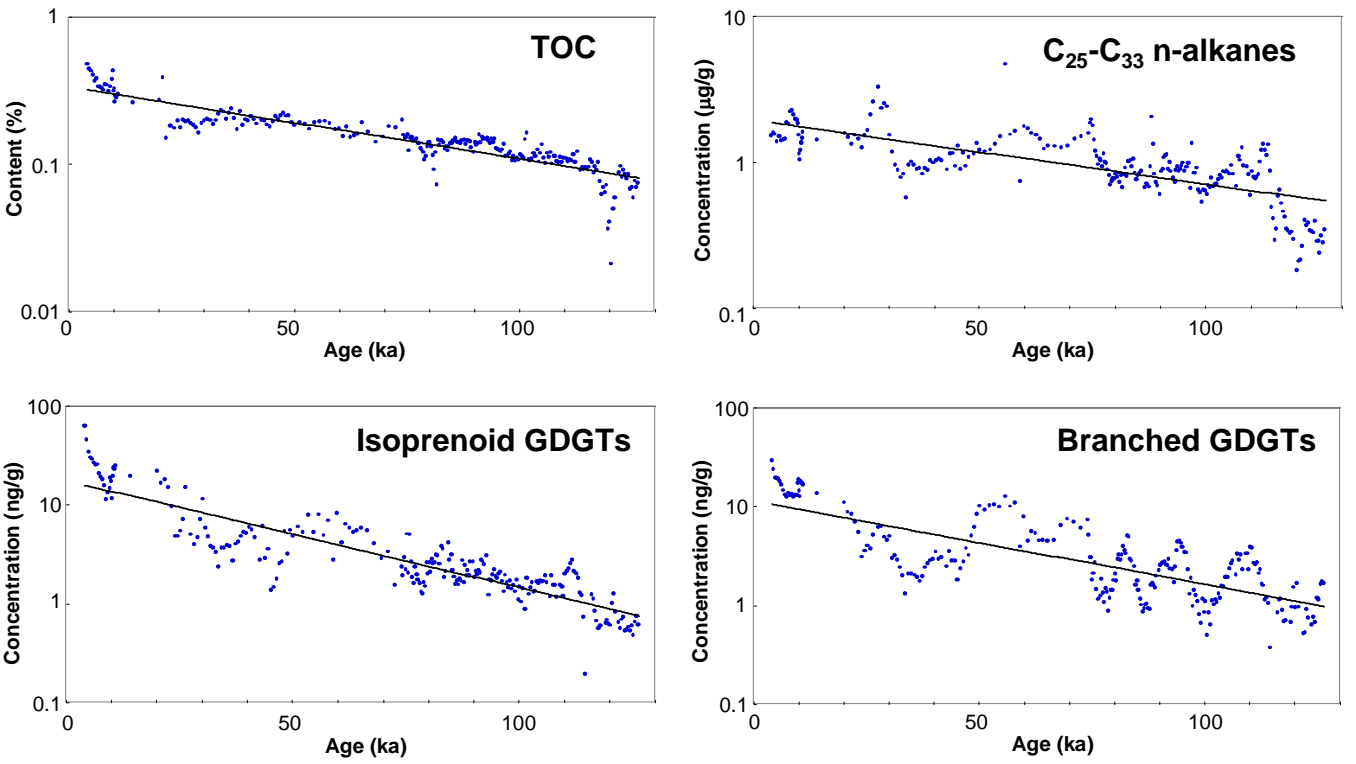

Fig. 5 


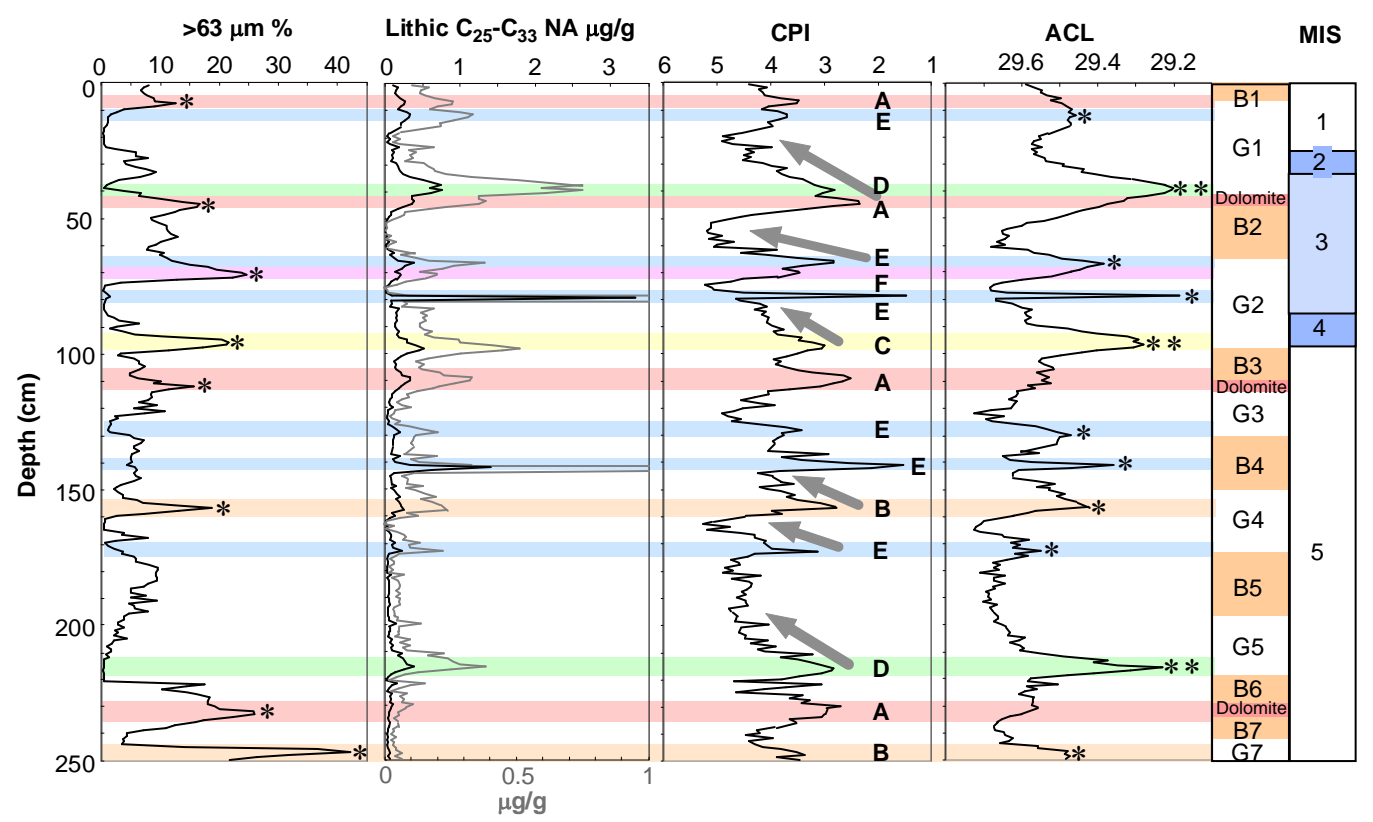

Fig. 6 